\title{
STOP 3: Late-glacial and early postglacial environmental processes and the history of the River Triečupite valley and surroundings, in the foreland of the Vidzeme Upland
}

Māris Krievāns and Laimdota Kalniņa

University of Latvia

The stop is located at the River Triečupite valley $\left(25^{\circ} 20^{\prime} 3.67^{\prime \prime} \mathrm{E}, 57^{\circ} 19^{\prime} 58.46^{\prime \prime} \mathrm{N}\right)$, in the Trikāta Rise, which forms a transitional zone between the Northern Vidzeme Lowland and the Vidzeme Upland (Fig. 3.1). It gives an insight into the geological structure, morphology and formation of the deep-cut glacial meltwater drainage valley system of the rivers Triečupite, Vaive and Rauna, presenting a pattern of terraced valleys created as a result of late-glacial meltwater activity and postglacial fluvial erosion, along with an example of apron-like calcareous tufa deposition.

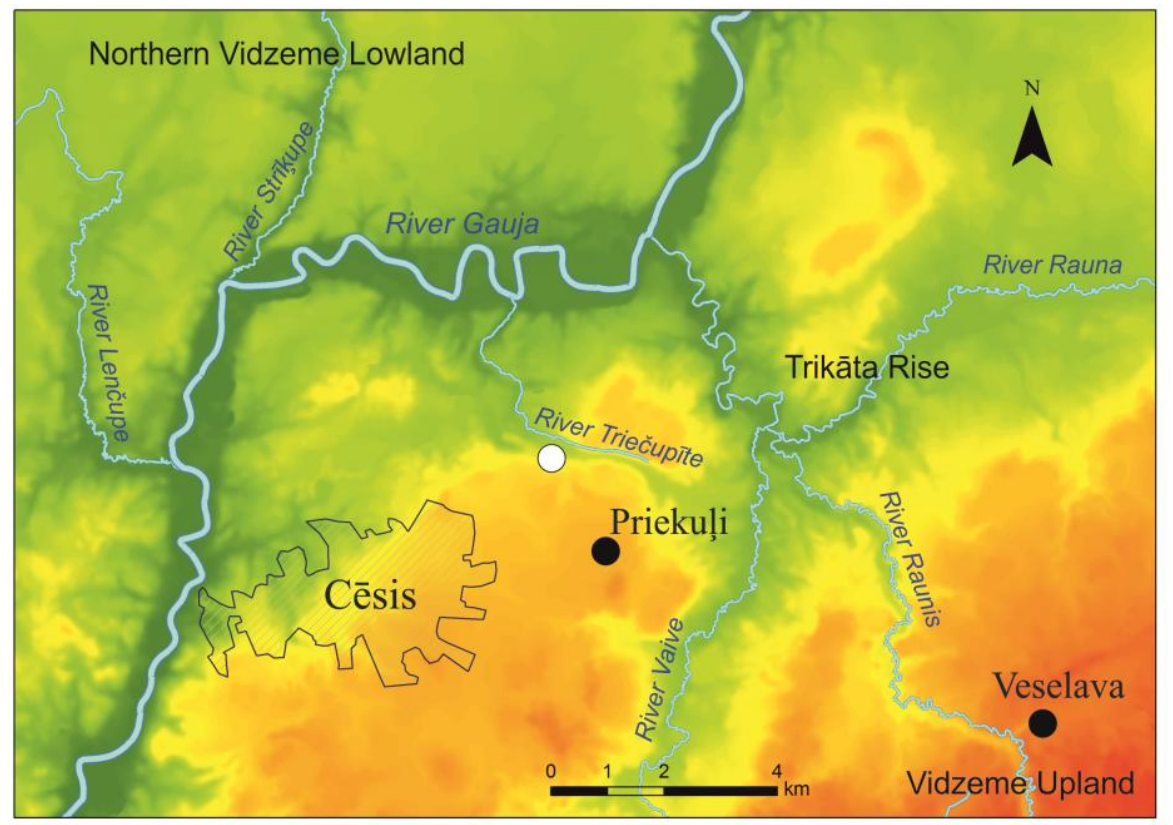

Fig. 3.1. Geographical location of the River Triečupite (Kazu grava) valley. White circle - location of Stop 3, black circles - villages.

The thickness of the Pleistocene deposits along the River Triečupite valley is less than $10 \mathrm{~m}$. They rest on Upper Devonian dolomite, underlain by Upper Devonian sandstone and clay. In places rafted blocks and subglacial till, composed mainly of the local bedrock, can be encountered. The present-day surface topography has been shaped by the Burtnieks ice lobe and meltwater activity, particularly during the initial transgression of the Late Weichselian Fennoscandian Ice Sheet and its oscillatory retreat, beginning approximately $15.2 \mathrm{ka}$ BP (Zelčs and Markots 2004; Zelčs et al. 2011).

\section{River Triečupite valley}

The Triečupite valley is about $3.6 \mathrm{~km}$ long and $0.3-0.8 \mathrm{~km}$ wide, and in the middle part its depth reaches 35-42 m. It crosses the watershed between the valleys of the rivers Vaive and Gauja. North-west of the Riga-Valka railway embankment the valley ramifies, forming a second, more elevated branch - Bušleja (Āboltiņš 1998). The River Triečupīte valley is confined to an ancient U-shaped buried valley which is incised into Middle Devonian silt, clay and sandstone, and Upper Devonian sandstone and dolomite (Bendrupe and Arharova 1981). 
The bedrock surface alongside the valley is $110 \mathrm{~m}$ a.s.l., but at the bottom of the valley it varies from $70 \mathrm{~m}$ a.s.l. in the middle course up to $50 \mathrm{~m}$ a.s.l. in the direction of both ends. In the lowest part of the Triečupite valley the bedrock is covered by Upper Pleistocene till. According to Juškevičs (2000) and Āboltiņš (1998), this indicates formation of the valley in proglacial conditions during at least part of the last Fennoscandian Ice Sheet transgression. The development of the present valley and transformation of the glacial relief in the adjoining area began with the retreat of the Burtnieks ice lobe from the marginal formations of the North Lithuanian (Linkuva) glacial phase. It can comparatively be correlated with the development of the valleys of the rivers Gauja, Rauna and Vaive as well as local meltwater basins during the Late Glacial. Alongside the slopes and within the Triečupite valley Holocene peat and alluvial sediments have accumulated (Āboltiņš 1995).

According to the field and geospatial data, the River Triečupite valley can be divided into three morphologically distinct parts - the north-western extension, the middle part and the south-eastern extension (Fig. 3.2.). In the SE extension two glaciolacustrine terraces were traceable at levels of 74 and $77 \mathrm{~m}$ a.s.l., and the highest glaciolacustrine terrace was detected at $87 \mathrm{~m}$ a.s.l. The terraces are composed of fine-grained and medium-grained sand.

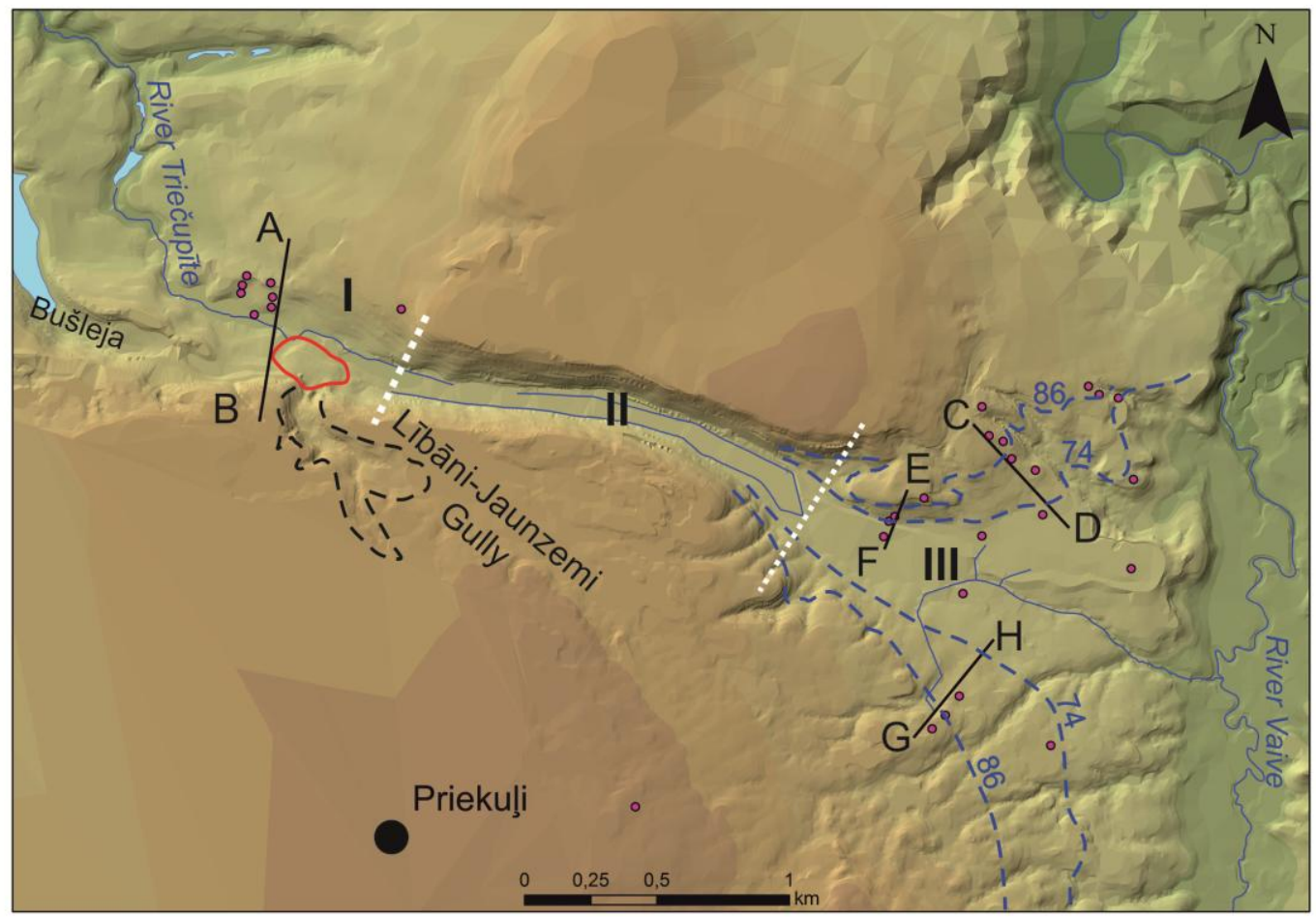

Fig. 3.2. Digital elevation model of the River Triečupite valley and surrounding area. Solid black lines show location sites of profiles; red dots indicate the location of boreholes; blue dashed lines indicate the shorelines of the Kārklini palaeobasin; the contour marked by a red solid line denotes the location of the freshwater tufa apron; white lines separate geomorphologically distinct parts of the River Triečupite valley: I - north-western extension; II - middle part; III - south-eastern extension.

The thickness of glaciolacustrine sediments varies from some tens of centimetres to a few metres. In the NW extension three terraces can be traced, at 72, 66 and $62 \mathrm{~m}$ a.s.1. (Fig. 3.3). The two highest are considered to be of erosional origin. In separate boreholes basin sediments have been detected at $65 \mathrm{~m}$ a.s.l. The middle part of the River Triečupite valley is non-terraced, with a U-shaped cross-section. Its slopes are very steep, in some places reaching the critical angle of repose. In the upper part of the valley the Upper Devonian Pl̦avinas Formation dolomite forms steep scarps. As result of suffosion of the underlying sandstone and subsequent subsidence and collapse of the cracked dolomite, a number of caves 
and sinkholes have formed. In total, eight caves occur on the right-bank slope of the river valley, as well as one cave on the left-bank slope. The best-known are Big Sikspārṇi, Medium Sikspārņi and Small Sikspārņi ('Bat') Caves. These are among the largest caves in Latvia, and are often erroneously classified as karst caves in dolomite. It is likely that the base level of the caves reflects the historic groundwater level that served as the base of suffosion.

On the basis of the spatial distribution of the fine-grained sediments, a model of the Kārkliņi palaeolake terraces has been developed (Fig. 3.2). According to this model, the palaeolake sediments and associated fluvial sedimentation occur in a much wider area than is displayed in a map by previous researchers (Zīverts and Arharova 1981), where the distribution of glacioaquatic sediments is restricted to a small area within the valley, at $75 \mathrm{~m}$ a.s.l. Between Vieksi Hill and near the Rauna-Mūrmuiža road within the valley of the River Rauna three shorelines of the Middle Rauna glacial lake can be identified, at 102, 80 and 76 m a.s.l.

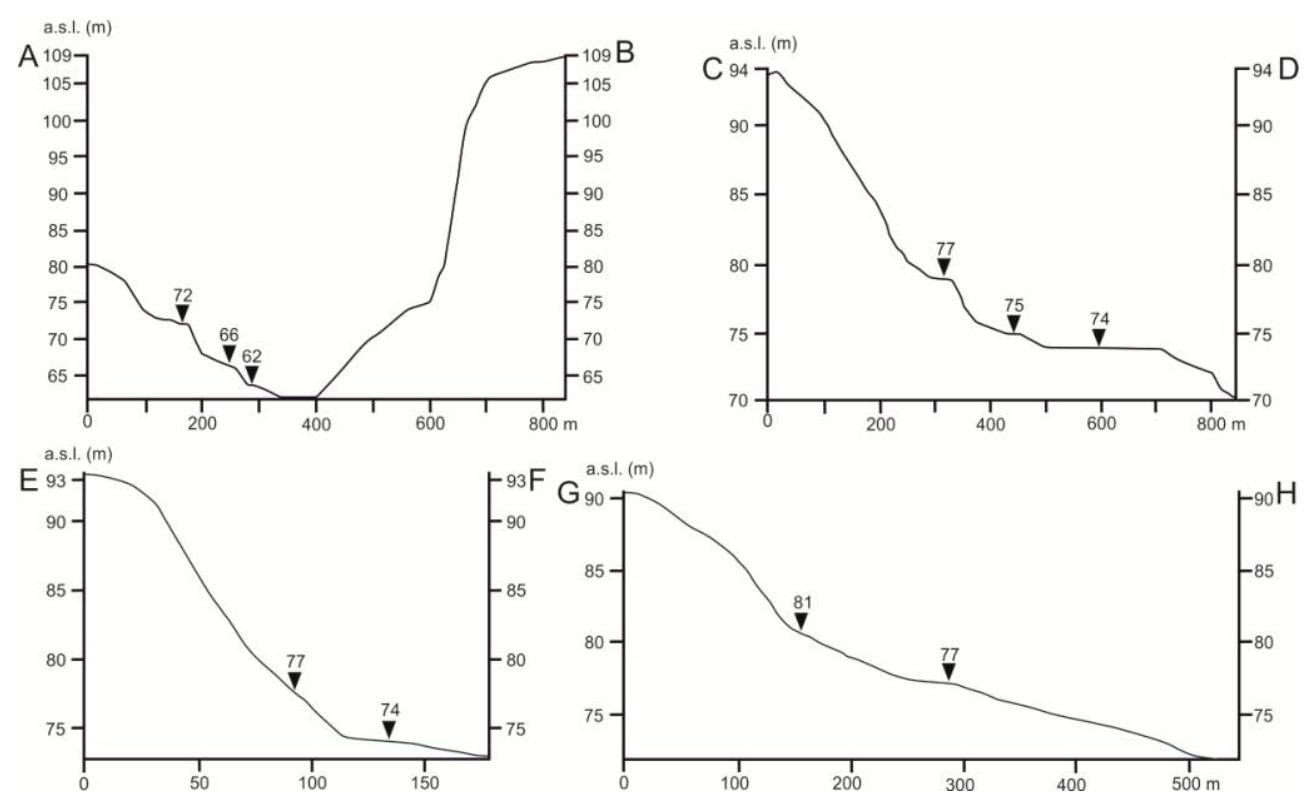

Fig. 3.3. Cross profiles of the Triečupîte valley. Triangles indicate detected terrace and shoreline levels.

Taking into account the hypsometric position of the shorelines of the Middle Rauna and Kārklini lakes, the layout of terrace-shaped forms, the surface topography and the distribution of the glacioaquatic sediments, it can be concluded that the Karrklini palaeobasin initially drained towards the west along the Bušleja into the Triečupite valley, forming a lateral meltwater drainage valley. Later on, after melting of the dead ice blocks in the depression located north of Bušleja, runoff occurred via the River Triečupite branch. The water level of the Kārkliṇi palaeobasin dropped discontinuously. Short-term stabilization phases are indicated by shorelines traceable along the southeastern extension.

\section{Palynological characteristics of the Lībāni-Jaunzemi freshwater tufa deposit}

The apron-like freshwater tufa deposit is located on the southern side of the Triečupite valley, where the Lībanni-Jaunzemi valley-like gully (Fig. 3.4), which is deeply incised into the Upper Devonian dolomite and sandstone, joins with the Triečupīte valley (Āboltiņš 1998). A freshwater tufa sequence up to 3.5-6 m high and $50 \mathrm{~m}$ wide is exposed in a quarry located at the mouth of the Lībāni-Jaunzemi valley-like gully. The total thickness of the freshwater tufa deposit (freshwater limestone, according to Āboltiņš 1998) reaches up to $12.2 \mathrm{~m}$ (Fig. 3.5).

Remains of fossil trees (branches, leaves and trunks) occur together with freshwater 
molluscs. Pollen analysis indicates that freshwater tufa precipitation started in the Boreal and lasted up to the Subatlantic (Danilāns 1957, 1973). The freshwater tufa deposit has an apronlike shape. According to Pedley (1990), freshwater tufa can be classified as a fluvial deposit precipitated by a spring. Spring water in this area has a high calcium carbonate content. Calcareous sediments were gradually deposited on the lower part of the slope. The small folds that occur in the tufa were created by sediment flows of the unconsolidated calcareous deposits (Āboltiņš 1998). However, these small-scale deformation structures are most likely responsible for the settling of the calcium carbonate on the roughened fluvial or mass-wasting erosional surface. The springs have formed a multi-level waterfall about $7 \mathrm{~m}$ high.

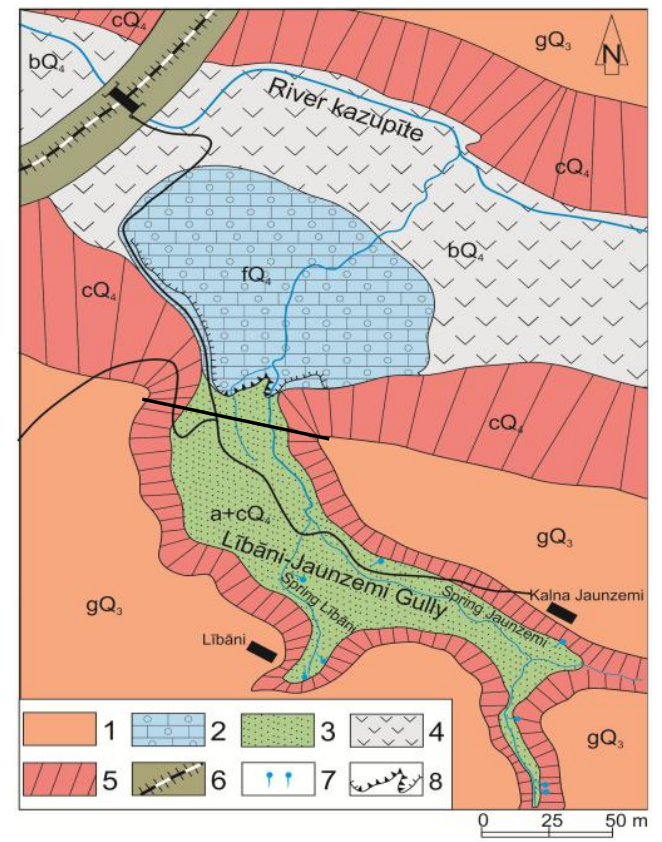

Fig. 3.4. Quaternary superficial sediments in the area of the Lībāni-Jaunzemi tufa deposit. 1 - Late Weichselian till $\left(\mathrm{gQ}_{3}\right) ; 2$ - freshwater tufa $\left(\mathrm{fQ}_{4}\right) ; 3$ - alluvial-colluvial sediments $\left(\mathrm{a}+\mathrm{cQ}_{4}\right) ; 4$ - peat $\left(\mathrm{bQ}_{4}\right) ; 5$ - colluvium $\left(\mathrm{cQ}_{4}\right) ; 6$ - railway embankment; 7 - springs; 8 - outcrop; black straight line indicates location of cross section shown in Fig. 3.5.

\section{A 7.60-m-long section of the Lībāni-Jaunzemji} tufa outcrop has been sampled for pollen analysis. These data have been used for approximate estimation of the time and environmental conditions of tufa deposition. A new pollen diagram constructed according to these data allows four local pollen assemblage zones (PAZ) to be distinguished (Fig. 3.6; Table 3.1). Zoning was done using correlations with pollen diagrams in the region and pollen data obtained from previous investigation on a 10.5-m-long sequence by A. Timšs (published in Danilāns 1957). Even though the current section is $2.9 \mathrm{~m}$ shorter, the pollen data show approximately the same characteristics of pollen spectra.

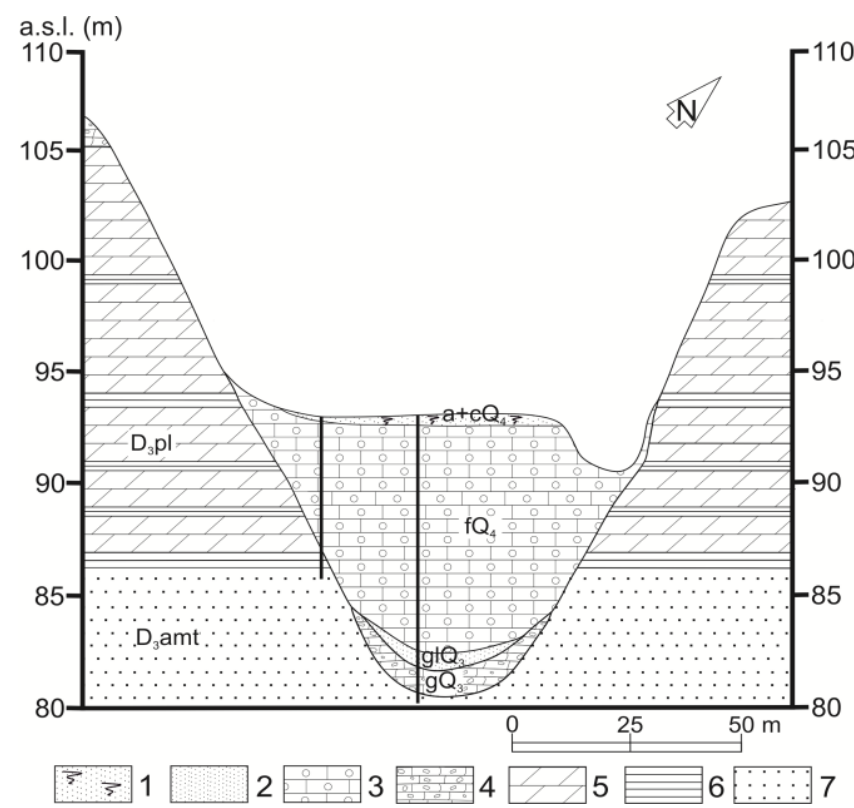

Fig. 3.5. Geological section across the LībāniJaunzemi valley-like gully (modified from Danilāns 1957).

Legend: 1 - alluvial-colluvial sediments $\left(\mathrm{a}+\mathrm{cQ}_{4}\right)$; 2 - glaciolacustrine sand $\left(\mathrm{glQ}_{3}\right) ; 3$ - freshwater tufa $\left(\mathrm{fQ}_{4}\right) ; 4$ - Late Weichselian till $\left(\mathrm{gQ}_{3}\right) ; 5$ Upper Devonian dolomite of Plavinas formation $\left(\mathrm{D}_{3} \mathrm{pl}\right) ; 6$ - Upper Devonian clay interlayers; 7 Upper Devonian sandstone of Amata formation ( $\left.\mathrm{D}_{3} \mathrm{amt}\right)$. See Fig. 3.4 for location of section.

Pollen spectra in both diagrams suggest that the most intensive freshwater tufa precipitation occurred in the Early Holocene. Sandy tufa started to be deposited at the base of both analysed sections. The proportions of tree and shrub, or arboreal (AP) and herb or non-arboreal (NAP) pollen point to a partly open mosaic landscape during the time of deposition of the freshwater tufa. No relationship has been identified between 
the pollen composition and variation in tufa types.

Table 3.1. Local pollen assemblage zones of the Lībāni-Jaunzemji tufa outcrop section.

LPAZ and chronology

LJ4

Betula-Alnus-Pinus (beginning of the

Holocene Thermal

Maximum, i.e.

beginning of the

Atlantic - AT1)

LJ3

Betula-Alnus-Pinus

(end of the Early

Holocene, i.e. 2nd part

of the Boreal - $\mathrm{BO} 2$ )

\section{LJ2 \\ Pinus}

(2nd part of the Early

Holocene, i.e. 1st part of the Boreal - BO1)

\section{LJ1 \\ Betula-Pinus \\ (1st part of the Early \\ Holocene - Preboreal)}

Description of zone

This zone is characterized by stable records of Pinus (50-55\%) and Betula (15-20\%) pollen, an increase of alder (Alnus) to $10 \%$ and hazel (Corylus) pollen up to $6 \%$, as well as the empirical maxima of pollen values of broadleaved trees, varying from 0.5 to $3 \%$. Picea percentages increase, reaching $2.8 \%$. Some increase is also characteristic for herb pollen, mainly represented by Poaceae, Cyperaceae, Ranunculaceae and Aster type.

The lower part of the laminated tufa and dense tufa in the depth interval 1.8-3.35 m contains pollen with a composition indicating a decrease of pine forest in the area, some increase in Betula, Alnus and Corylus, and the appearance of Ulmus. The occurrence of Picea and increase in ruderal plants suggest some changes in vegetation and climate. Particularly the increase in Plantago, Chenopodiaceae, Rumex and Rubiaceae indicates the possibility of human activity in the area. Spores are mainly represented by green algae Bryales and ferns Polypodiaceae.

Represented by clayey freshwater tufa in the lower part of the zone interval $(6.4-6.9 \mathrm{~m})$ and dense freshwater tufa in the upper part. Betula pollen significantly decreases and Pinus reaches its maximum (80\%) in the pollen diagram above the previous zone. The dominance of Pinus is characteristic for the first half of the Boreal in the pollen spectra of pollen diagrams for Latvia. There is still a significant presence of various herbs, suggesting that the surrounding area was not covered by dense forest. Pollen of pasture/meadow plants and also Plantago and Urtica indicates some presence of man in the area during the first half of the Boreal.

Pollen spectra indicate the dominance of Betula sect. Albae and a comparatively high amount of Pinus and herbs in the lower part of sediment sequence of the section represented by clayey and silty freshwater tufa overlying the sandy tufa at the base of the section. The herb pollen is mainly represented by Poaceae, Cyperaceae and ruderal herbs, such Artemisia and Chenopodiaceae. Total pollen composition points to a partly open landscape, covered by sparse pine-birch forest accompanied by a rich grass community. Comparison with regional pollen spectra indicates that the zone described may be correlated with the Preboreal (PB).

Many studies of freshwater tufa in Central Europe using radiocarbon datings and pollen analysis show that a peak of tufa precipitation occurred during the Atlantic and Subboreal climatic periods (5000-2500 BP) of the Holocene, when climatic conditions were warmer and wetter (Goudie et al. 1993; Banks et al. 2012). Freshwater tufa deposits in Latvia have not been dated by radiometric dating methods. The age of the freshwater tufa has been estimated approximately using pollen data. The pollen data from the new section of the Lībāni-Jaunzemi deposit allow us to conclude that the largest volume of tufa was formed before the cold event of $8200 \mathrm{cal}$ yr. BP, which is clearly expressed by a sharp peak of birch (Betula) pollen and a brief decrease in alder, hazel and broadleaved pollen (Seppä et al. 2007). This is in good agreement with studies in the Pudost massif (Nikitin et al. 2011), where accumulation of freshwater tufa (paratravertine) was determined as having occurred from $7.5 \pm 0.4$ to $6.8 \pm 0.4 \mathrm{ka}$ BP. 


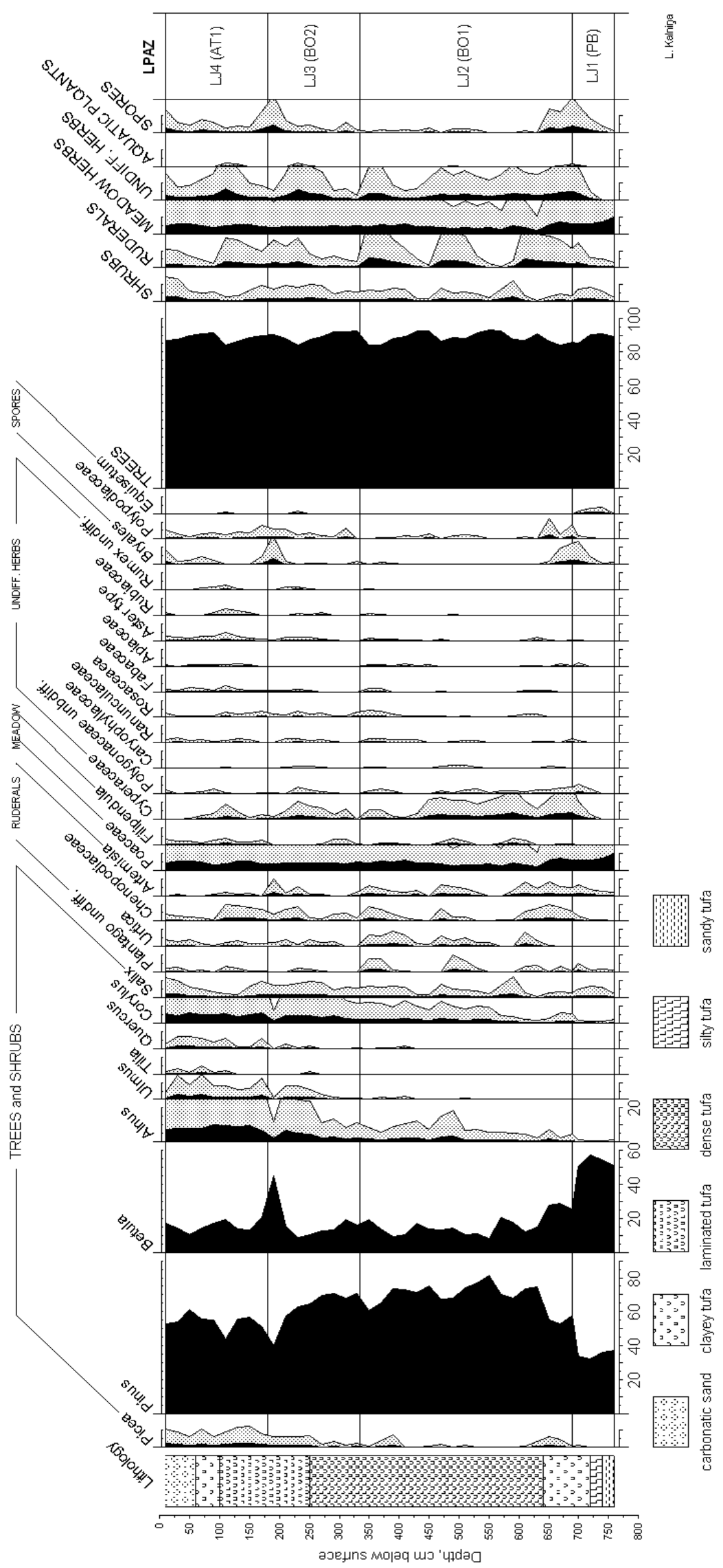

Fig. 3.6. Pollen percentage diagram for the Lībāni-Jaunzemi freshwater tufa outcrop. 
Most of the largest freshwater tufa deposits (Lake Vilgale, Pikste, Seriestade, LībāniJaunzemji) in different regions of Latvia have been studied palynologically. According to palynological data it can be concluded that freshwater tufa started to precipitate at least in the Early Holocene. In many cases the accumulation of freshwater tufa ended during the first half of the Holocene Thermal Maximum, but this also depended on the local geological conditions.

\section{References}

Āboltiņš, O. 1998. STOP 14. Holocene freshwater limestone and outcrop at Priekuļi, the vicinity of Cēsis. In Zelčs, V. (ed.), Field Symposium on glacial processes and Quaternary environment in Latvia. Excursion guide. University of Latvia Rīga, 25-31 May, 1998. University of Latvia, Rīga, pp. 79-82.

Āboltiņš, O. 1995. Kazu ieleja. Grām. Kavacis, G. (atb. red.), Latvijas daba, 2. Latvijas Enciklopēdija, Rīga, lpp. 238.

Āboltiņš, O.P. 1975. Glaciodynamic peculiarities of formation of Latvian elevations. Problems of Quaternary geology, 8, pp. 5-23 (in Russian).

Banks, V.J., Jones, P., Lowe, D.J., Lee, J., Rushton, J., Ellis, M.A. 2012. Review of tufa deposition and palaeohydrological conditions in the White Peak, Derbyshire, UK: implications for Quaternary landscape evolution. Proceedings of the Geologists' Association, 123(1), 117-129.

Bendrupe, L., Arharova, T. 1981. Geologicheskaya karta (dochetvertichnye otlozheniya) masshtaba 1:50000 [Geological map (pre-Quaternary deposits) in scale of 1:50,000]. Prilozhenije $k$ otchetu o gruppovoy geologicheskoy syomke masshtaba 1:50 000 Gaujskogo natsionalnogo parka. Upravlenije geologii, Riga, 1-3 list. Valsts ǵeologijas fonds, ID No.2095, Inv. No.09855 (In Russian).

Danilāns, I. 1957. Golotsenovyje presnovodnyje izvestkovyje otlozhenija Latvii [Holocene freshwater calcareous sediments of Latvia]. Rīga, Publishing House Academy of Science of Latvian SSR, 162 pp. (In Russian)

Danilāns, I. 1973. Chetvertichnye otlozheniya Latviji [Quaternary deposits of Latvia]. Zinātne, Rīga, 312 pp. (In Russian).

Goudie, A.S., Viles, H.A., Pentecost, A. 1993. The late-Holocene tufa decline in Europe. The Holocene, 3, $181-186$.

Juškevičs, V. 2000. Quaternary deposits. In: Āboltinš, O., Kuršs, V. (eds.), Geological Map of Latvia. Scale 1:200,000. Sheet 43-Rīga. Sheet 53-Ainaži. Explanatory Text and Maps. State Geological Survey, Rīga, pp. 10-31.

Nikitin, M.U., Medvedeva, A.A., Maksimov, F.E., Kuznetsov, V.Yu., Zherebtsov, I.E., Levchenko, S.B., Baranova, N.G. 2011. Genezis i geologicheskiy vozrast travertinopodobnykh karbonatov Pudostskogo massiva [The origin and the geological age of the travertine-like carbonates of the Pudost massif]. Journal "Society. Environment. Development" ("TERRA HUMANA"), 2011(4), 231-236 (in Russian).

Pedley, H.M. 1990. Classification and environmental models of cool freshwater tufas. Sedimentary Geology, 68, 143-154

Seppä, H., Birks, H. J. B., Giesecke, T., Hammarlund, D., Alenius, T., Antonsson, K., Bjune, A. E., Heikkilä, M., MacDonald, G. M., Ojala, A. E. K., Telford, R. J., Veski, S. 2007. Spatial structure of the $8200 \mathrm{cal}$ yr BP event in northern Europe. Climate of the Past, 3, 225-236.

Zīverts, A, Arharova, T. 1981. Geologicheskaya karta (chetvertichnye otlozheniya) masshtaba 1:50000 [Geological map (Quaternary deposits) at scale 1:50,000]. Prilozhenije $k$ otchetu o gruppovoy geologicheskoy syomke masshtaba 1:50 000 Gaujskogo natsionalnogo parka. Upravlenije geologii, Riga, 5-6 list. Valsts ğeoloğijas fonds, ID No.2095, inv. No.09855 (in Russian)

Zelčs, V., Markots, A. 2004. Deglaciation history of Latvia. In: Ehlers, J., Gibbard, P. L. (eds.), Quaternary Glaciations - Extent and Chronology. Part I: Europe. Developments in Quaternary Science, 2. Elsevier, Amsterdam, pp. 225-243.

Zelčs, V., Markots, A., Nartišs, M., Saks, T. 2011. Chapter 18: Pleistocene Glaciations in Latvia. In: Ehlers, J., Gibbard, P.L., Hughes, P.D. (eds.), Quaternary glaciations - extent and chronology. A closer look. Developments in Quaternary Science, 15. Elsevier, pp. 221-229. 

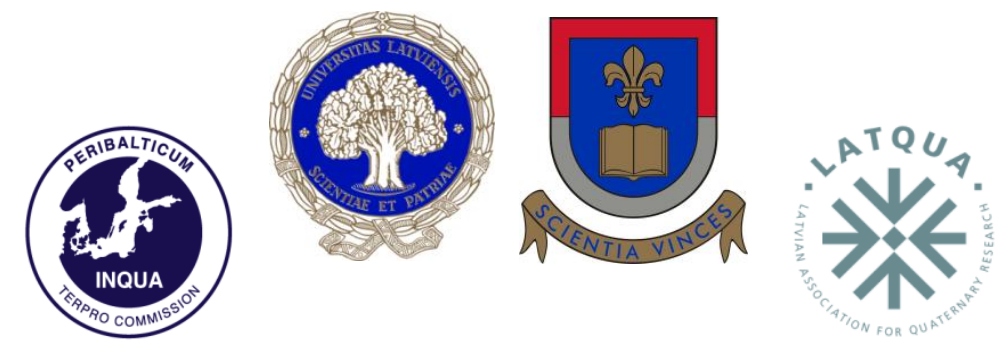

INQUA TERPRO COMMISSION PERIBALTIC WORKING GROUP

UNIVERSITY OF LATVIA

UNIVERSITY OF DAUGAVPILS

LATVIAN ASSOCIATION FOR QUATERNARY RESEARCH

\section{LATE QUATERNARY \\ TERRESTRIAL PROCESSES, SEDIMENTS AND HISTORY: FROM GLACIAL TO POSTGLACIAL ENVIRONMENTS}

EASTERN AND CENTRAL LATVIA

AUGUST 17-22, 2014 


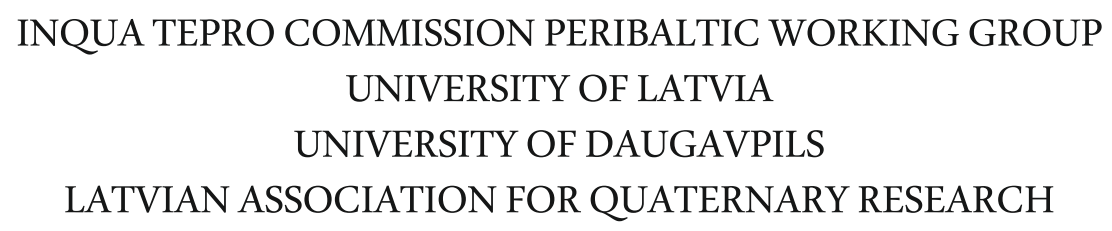

\title{
LATE QUATERNARY \\ TERRESTRIAL PROCESSES, SEDIMENTS AND HISTORY: FROM GLACIAL TO POSTGLACIAL ENVIRONMENTS
}

\author{
EASTERN AND CENTRAL LATVIA
}

AUGUST 16-22, 2014 
Organized by:

University of Latvia

Daugavpils University

Latvian Association for Quaternary Research

INQUA Peribaltic Working Group (INQUA TERPRO Commission)

Organizing committee:

Māris Nartišs (Chair, University of Latvia)

Māris Krievāns (Secretary, University of Latvia)

Aivars Markots (University of Latvia)

Juris Soms (Daugavpils University)

Evija Tērauda (University of Latvia)

Vitālijs Zelčs (University of Latvia)

Contributors:

Ivars Celiņš, Edgars Greiškalns, Ieva Grudzinska, Edyta Kalińska-Nartiša, Laimdota Kalniņa, Jānis Karušs, Māris Krievāns, Kristaps Lamsters, Aivars Markots, Māris Nartišs, Agnis Rečs, Normunds Stivriņš, Juris Soms, Ivars Strautnieks, Santa Strode, Sandra Zeimule, Vitālijs Zelčs

Editors: Vitālijs Zelčs and Māris Nartišs

The English texts of the field guide were revised by Valdis Bērziņš

Recommended reference for this publication:

Zelčs, V. and Nartišs, M. (eds.) 2014. Late Quaternary terrestrial processes, sediments and history: from glacial to postglacial environments. Excursion guide and abstracts of the INQUA Peribaltic Working Group Meeting and field excursion in Eastern and Central Latvia, August 17-22, 2014. University of Latvia, Rīga, 2014, 150 pages.

Sponsored by:

University of Latvia

Layout: Vitālijs Zelčs, Māris Nartišs and Māris Krievāns

ISBN 078-9934-517-60-0

(C) University of Latvia, 2014

This volume is available from:

Faculty of Geography and Earth Sciences

University of Latvia

Rainis Blvd. 19

Rìga, LV1586

Latvia 